4. Юсупова В.В. Методики диагностирования детей дошкольного возраста. - М.: АПКиПРО, 2014. - 29 с.

5. Стребелева Е.А., Мишина Г.А., Разенкова Ю.А. и др. Психолого-педагогическая диагностика развития детей раннего и дошкольного возраста. - М.: Просвещение, 2004. $-164 \mathrm{c}$.

\title{
Образовательная роботехника как основа развития технических умений учащихся
}

\author{
Иванов С.К., студент, \\ Северо-Восточный федеральный университет, \\ 2. Якутск \\ E-mail: ksaverievi4@mail.ru
}

Научный руководитель: д.n.н. Степанов П.А.

Образовательная робототехника в школе приобретает все большую значимость и актуальность в настоящее время. Занятия по робототехнике знакомят учащихся с законами реального мира, учат применять теоретические знания на практике, развивают наблюдательность, мышление, сообразительность, креативность. Программирование реального робота поможет увидеть законы физики, математики, информатики не на страницах тетради или учебника, а в окружающем мире. Так как использование конструкторов Lego Mindstorms NXT позволяет взглянуть на школьные предметы поновому. Разработана программа кружковых занятий по робототехнике. Кружок работает для школьников, в котором ребята программируют и создают роботов. Идет разработка задачника по робототехнике. Проводятся тематические мероприятия для школьников. Привлечение школьников к исследованиям в области робототехники, обмену технической информацией и начальными инженерными знаниями, развитию новых научно-технических идей позволит создать необходимые условия для высокого качества образования. Внедрение системы обучения основам робототехнике будет являться важным этапом развития технических навыков и умений школьников.

За последние годы успехи в робототехнике и автоматизированных системах изменили личную и деловую сферы нашей жизни. Сегодня промышленные, обслуживающие и домашние роботы широко используются на благо экономик ведущих мировых держав [1].

Возникает противоречие между быстроразвивающимися темпами робототехники и недостаточной обеспеченностью инженерными кадрам, а также, низким статусом инженерного образования при выборе будущей профессии выпускниками школ. Поэтому сейчас просто необходимо активно начинать популяризацию профессии инженера в средней школе. Детям нужно иметь представление о современной и перспективной инженерной деятельности.

С развитием автоматизации производственных и некоторых мыслительных процессов возникла потребность в теории, которая могла бы обобщить и научно обосновать приемы и средства создания автоматических управляющих устройств. Такая теория, оформившаяся за последние пятнадцать лет в самостоятельное научное 
направление, получила название кибернетики.

Предмет робототехники - это создание и применение роботов, других средств робототехники и основанных на них технических систем и комплексов различного назначения. Возникнув на основе кибернетики и механики, робототехника в свою очередь породила новые направления развития и самих этих наук.

Согласно национальной образовательной инициативе утвержденной Д.А. Медведевым, современное образование должно соответствовать целям опережающего развития. Для этого должно быть обеспечено:

- изучение не только достижений прошлого, но и технологий, которые пригодятся в будущем;

- обучение, ориентированное как на знаниевый, так и деятельностный аспекты содержания образования.

Таким требованиям отвечает робототехника. Термин «образовательная робототехника» означает различное межпредметное использование роботов и прочих подобных систем в обучении детей, как на урочной, так и во внеурочной деятельности.

\section{Постановка задачи.}

Интенсивная экспансия искусственных помощников в нашу повседневную жизнь требует, чтобы пользователи обладали современными знаниями в области управления роботами, что позволит быстро развивать новые, умные, безопасные и более продвинутые автоматизированные и роботизированные системы. Чтобы удовлетворить эту потребность, образовательные учреждения должны адекватно реагировать на высокие требования к специалистам в области робототехники, разрабатывая и предлагая соответствующие курсы для учащихся, популяризируя область роботостроения и автоматизированных систем.

Сейчас наша основная задача - охватить как можно больше учащихся с целью привлечения ее к науке и инженерному делу через обучение основам робототехники.

\section{Описание исследования.}

Образовательная робототехника в школе приобретает все большую значимость и актуальность в настоящее время. Учащиеся, начиная с начальных по 11 классы школ вовлечены в учебный процесс создания моделей - роботов, проектирования и программирования робототехнических устройств.

Объективной причиной возникновения и развития современной робототехники явилась историческая потребность производства в гибкой автоматизации с устранением человека из непосредственного участия в машинном производстве и недостаточность для этой цели традиционных средств автоматизации. Поэтому задачей робототехники наряду с созданием собственно средств робототехники является разработка основанных на них систем и комплексов различного назначения. Системы и комплексы, автоматизированные с помощью роботов, принято называть роботизированными. Роботизированные системы, в которых роботы выполняют основные технологические операции, называются робототехническими.

Также важно понимать, что робототехника на разных ступенях образования имеет различные цели. Поэтому рекомендуется, в зависимости от возраста учащихся, использовать конструкторы разных типов, проводить различные мероприятия, изучать всевозможные темы. Сегодня это возможно при организации специальных кружков по робототехнике, факультативов и элективных курсов. Безусловно, помимо основных занятий по робототехнике, нужно проводить различные внешкольные мероприятия, позволяющие привлечь интерес к данному направлению. Это могут быть конкурсы по 
робототехнике, круглые столы, викторины, мастер - классы по конструированию и программированию роботов, а также олимпиады, где юные таланты могут посоревноваться и поделиться собственным опытом [2].

Я начал заниматься внедрением робототехники в образование со своей родной школы, изучил педагогическую и методическую литературу, разработал план и конспекты занятий кружка по робототехнике и приступил к практической работе четыре года назад.

Дирекция школы прислушалась к моим доводам и охотно и предоставила средства на покупку конструкторов Lego Mindstorms NXT. Таким образом, на настоящее время у нас есть три робототехнических конструктора, которые и позволили нам добиться следующих результатов:

1. Разработана программа кружковых занятий по робототехнике. Занятия по данной программе проводятся еженедельно.

2. Идет разработка задачника по робототехнике, который согласуется с целями и задачами стоящим перед курсом школьной информатики.

3. Проведено больше десятка мероприятий для школьников: семинаров, лекций, презентаций по робототехнике.

4. Проведено внутришкольное соревнование по робототехнике.

Разбивка заданий для занятий с усложнением задач планируется с учетом как начального уровня знаний детей, так и в процессе преподавания робототехники с учетом усвоения материала. Общий ход занятия выглядит приблизительно так:

- Постановка задачи;

- Способы ее решения логическим путем и определение какие именно команды должен выполнить робот;

- Конструирование робота с необходимыми блоками, моторами и сенсорами;

- $\quad$ Программирование;

- Отработка на полигоне;

- $\quad$ Размышление что можно улучшить или изменить в конструкции робота или программе для более качественного решения поставленной задачи.

- $\quad$ При подготовке к выставкам и соревнованиям разбор правил проведения мероприятия и технических характеристик необходимых роботов.

На мой взгляд, робототехника в школе представляет учащимся технологии XXI века, способствует развитию их коммуникативных способностей, развивает навыки взаимодействия, самостоятельности при принятии решений, раскрывает их творческий потенциал. Ученики лучше понимают, когда они что-либо самостоятельно создают или изобретают. При проведении занятий и мероприятий по робототехнике этот факт не просто учитывается, а реально используется.

Введение элементов робототехники в школьные предметы позволит заинтересовать учащихся, разнообразить учебную деятельность, использовать групповые активные методы обучения, решать задачи практической направленности. Программирование реального робота поможет увидеть законы математики не на страницах тетради или учебника, а в окружающем мире. Программирование роботов позволяет без усилий организовать межпредметные связи информатики с математикой и физикой, при специальной подготовке учителя и наличии методических материалов - с кибернетикой, физиологией и психологией.

В заключении отмечу, что внедрение единой системы обучения основам 
робототехнике в школе будет являться важным этапом развития технических умений учащихся.

Список литературы:

1. Ершов М.Г. Роль образовательной робототехники в формировании инженерного мышления школьников. - URL: http://confer.cschool.perm.ru/tezis/Ershov.doc

2. Ушаков А.А. Робототехника в средней школе - практика и перспективы. URL: www.uni-altai.ru/info/journal/vesnik/3365-nomer-1-2010.html

\section{Исследование особенностей выявления одаренности у детей дошкольного возраста}

Калаиникова Е.А., педагог-психолог, ДОУ «Солнышко», п. Чульман E-mail: 721-00-00@mail.ru

Одна из насущных задач современного образования - выявление, поддержка и развитие творческой, креативной личности. Соответственно, научная обоснованность, технологическая проработанность формирования творческой, креативной личности в настоящем приобретают актуальность и значимость.

О том, что проблема выявления одаренности у дошкольника действительно существует, доказывают исследования ученых. На международной научнопрактической конференции «Современные тенденции развития дошкольного образования в мире» был представлен доклад доктора психологических наук, профессора Психологического института РАО Богоявленской Дианы Борисовны по теме «Проблемы выявления одаренности в дошкольном возрасте».

В реальной практике дошкольных учреждений, остро ощущается необходимость постановки целенаправленной, планомерной и систематической работы педагогического коллектива по выявлению, поддержанию и развитию одаренных дошкольников. В эту работу должны быть включены родители, психологи и педагоги.

Совершенствуя условия для выявления и поддержки одаренных детей, Постановлением Правительства Российской Федерации от 17 ноября 2015 г. № 1239 утверждены правила выявления детей, проявивших выдающиеся способности, сопровождения и мониторинга их дальнейшего развития.

Интеллектуальность - по коэффициенту интеллекта выявляют одаренных детей, и это один из немногих бесспорных до недавнего времени признаков одаренности.

Базовым психическим процессом, обеспечивающим развитие интеллекта в младшем дошкольном возрасте, выступает восприятие и наглядно-действенное мышление. Следовательно, при диагностике интеллектуального развития нами подбирались такие методики и задания, которые учитывали возможности восприятия и наглядно-действенного мышления для организации предметной, игровой, продуктивной деятельности испытуемых. Базовым психическим процессом в старшем дошкольном возрасте является память. В основе многих методик диагностики интеллектуального развития старших дошкольников лежит тест на выявление общей осведомленности испытуемых в разных областях знаний и окружающем мире.

В методике А.Р. Лурия детей можно попросить подобрать картинки или символы, которые помогут им лучше запомнить называемые взрослым слова, и объяснить свой 